\title{
PUBLIC ENTITIES THROUGH THE LOOKING GLASS: A DISCLOSURE ASSESSMENT STUDY ON ROMANIAN MUNICIPALITIES
}

\author{
Tudor Oprişor ${ }^{1}$ \\ Cristina-Silvia Nistor ${ }^{2}$
}

\begin{abstract}
Recent trends in organizational reporting show that improved disclosure levels are increasingly important for public sector entities, as they employ publicly available resources in their activity and are accountable towards various impacted stakeholders. Thus, enhancing transparency is a mean to justify the use of and effects on the elements which have a significant role in the economic environment of the entity. This study aims to pinpoint the main elements of disclosure (of different complexity levels) in the case of Romanian municipalities, using public sources of data and determine the overall level of disclosure with a refined assessment model (linked with previouslydeveloped instruments). The added value of this study is the integrated approach of the disclosure assessment process for Romanian local public administration, focusing on both the financial and nonfinancial sides. The findings show that Romanian municipalities exhibit a level of transparency which is more elevated than expected - with sufficient instruments of disclosure publicly available, and the focus does not fall solely on financial information (although it is prioritized through the lens of accountability for the use of public funding).
\end{abstract}

Keywords: transparency, accountability, disclosure, municipalities, public sector

JEL codes: $M 40, M 41$

\section{Introduction}

In the context of paradigm dynamics from the recent years, public sector entities are constantly seeking to reduce information asymmetry between them and their main stakeholders. The main motivation for this trend (at least in the case of public sector entities) is that a transparency enhancement process is an efficient way to provide the frame for evaluating resources use (and, implicitly, to discharge accountability towards taxpayers and other impacted parties).

Nevertheless, the justification of public financial resources is an issue which needs to be addressed by public sector reporting entities. In this respect, an increased level of transparency is supposed to reduce the probability of hindrances in assessing the adequate use of such resources. This assumption is grounded for non-financial resources, as well, only that the prioritization differs (as the financial capital holds a special interest and has a more prominent dynamic).

Within this paper, our main objective is to devise a transparency assessment tool for public sector entities and to reveal which elements of disclosure from the reporting output are held most important by reporting entities (and, by contrast, which ones are overlooked). We acknowledge that this approach requires a refinement from previously developed tools, as well as an update and

${ }^{1} \mathrm{PhD}$ Candidate \& Research Assistant, Babeş-Bolyai University of Cluj-Napoca, Faculty of Economics and Business Administration; Cluj-Napoca, România, E-mail: tudor.oprisor@econ.ubbcluj.ro.

${ }^{2}$ Associate Professor, Babeş-Bolyai University of Cluj-Napoca, Faculty of Economics and Business Administration, ClujNapoca, România, E-mail: cristina.nistor@econ.ubbcluj.ro. 
restructuring process in terms of framing. The main ground for our research is represented by the transparency assessment model developed by Ştefănescu et al (2016), which is largely based on the Integrated Reporting six-tier capital model and the Global Reporting Initiative guidelines. Furthermore, we narrow our focus and intend to assess the level of transparency for a sample of Romanian municipalities using a refined version of this model. Consequently, we drive our research forward intending to provide a solution to the following research question:

To which extent do Romanian municipalities disclose financial and non-financial information structured through the lens of the integrated reporting capitals model?

To meet our objective, we need to set a research direction and several boundaries. First of all, in the following section, we conduct a brief literature review, emphasizing the main delineations for the concept of transparency, to emphasize the dynamics and the outliers, as well as the connection with other instances and dimensions of the public sector (such as, accountability, politics, new technologies, etc.). This conceptual insight would allow the construction of an argumentative structure for the incentive of a high transparency level, with evidence on how it would impact the activity of a public sector entity and, also, how it could be achieved.

Afterwards, in a distinct methodological section, we describe in detail the way in which we refine our transparency assessment model, using elements from a set of previously-developed construct, based on an integrated approach. We then test the transparency assessment model on a selected sample of 39 Romanian municipalities and interpret the results, based on various descriptive metrics, to have an analytic view on the overall level of transparency exhibited by these entities. Last, but not least, conclude our study by emphasizing a series of insights from our findings, contributing to a better understanding of municipalities' disclosure patterns, as well as limitations and perspectives for future research.

\section{The concept of "transparency": a myriad of delineations}

On a conceptual level, transparency is defined as "legal, political and institutional structures that make information about internal characteristics of government and society available to actors both inside and outside of the domestic political system." Also, transparency involves some significant features such as easy access, timeliness, quality, relevance, comprehensiveness, reliability, and comparability of the information (Kristiansen et al., 2009). Grimmelikhuijsen et al. (2013) define the transparency as "the availability of information about an organization or actor that allows external actors to monitor the internal workings or performance of that organization."

The transparency within the governmental operations is seen as a critical prerequisite for macroeconomic sustainability and good governance. Altogether, the countries defined by a relatively high degree of transparency have shown a greater fiscal discipline and, in many cases, have achieved a sounder economic performance than other comparable countries, regarding resource dispensation and cultural features. Also, the studies show a positive connection between the transparency and the performance (Kopits \& Craig, 1998).

Determining the proper level and the nature of transparency requires having a balance between four beliefs (Bannister \& Connolly, 2011): the public's right to know, the good governance, the costs and risks of delivery, and the right of the public servants to personal privacy.

Moreover, Grimmelikhuijsen et al. (2013) focus on three key features of the transparent information. So, the completeness of information refers to whether the information is fully disclosed and it should not be associated with the amount. Secondly, the color of information means the level of positiveness of the information. Regarding this feature of transparent information, it seems that scholars agree that information on the websites of governments tends to be exceedingly positive related to officials or actions. Last but not least, the transparent information is usable. Usability of information 
is the way in which information is provided to the public. Presenting the information in an understandable manner is important.

Transparency represents a value of accountability, taking into accounting that any organization must justify the chosen actions (Pina et al., 2007). Also, transparency is considered an essential element of the good governance. By using social media platforms and content syndication improves the public sector transparency, because it brings the agenda and the activities closer to the citizens and provide the information on some platforms used by the people, who no longer have to access the website of that public entity to obtain the information (Bonsón et al., 2012).

There are a series of actors involved in the construction of the transparency. Hence, governmental organizations take decisions, but in this process, they are influenced by a multitude of stakeholders in their environments regarding whether and how to increase or decrease the transparency. The interactions between the governmental organizations and stakeholders encounter within a wide variety of legal frameworks, and in different cultural contexts. Government transparency is built through some complex interactions among some political and social actors, following some formal and informal rules, and having access to a variety of innovator and always developing technologies. The technological options, the organizational behavior, the relational patterns or the legal frameworks have an influence on the evolution of the transparency practices (Meijer, 2013).

During the last decade, the European Union municipal governments have significantly expanded their presence on the Internet, and that makes easier for citizens to locate and access the official information, to interact with public officials and to operate online transactions (Pina et al., 2009). Many local governments use the website as a mechanism to enhance informative transparency and to notify the citizens about the financial and economical administration of the local government. Among others, the sites make publicly available some relevant information such as the liquidity of the municipal budget, the financial and patrimonial situation of the municipality, and some indicators that inform the citizens about progress made by the city in some technological, cultural, social, and economic matters. The citizens are seen as stakeholders, analyzing the provide information to assess the degree of fulfilment of politicians or their electoral commitments (Gandía \& Archidona, 2008).

Within the academic literature, there are a series of studies that investigate the influence of the Internet on the transparency of local governments. The study of Pina et al. (2007) examines the impact of e-government on the transparency, openness and accountability on the first 15 European Union Member States. The results of the study reveal that the e-government has an enormous potential to contribute to modernizing the government, improving the transparency, the accountability and the openness making the websites more interactive.

On the other hand, Kim \& Lee (2012) suggest that the degree of development of e-participants through e-participation influence positively their assessment of government transparency. Also, the results of the study reveal that there is a positive association between the perception of the eparticipants on the government decision- making process and their assessment of the transparency of government. Moreover, the results show that the evaluation of the transparency is influenced by the trust in the governments. Another study that finds that the website of a local government plays a prominent role in the transparency belongs to Armstrong (2011). The same study suggests that the smaller communities more focused on public accessibility may be considered more transparent than large communities differently focused. Also, increased transparency and visibility in decision-making process improves the accountability (Brooks, 2000).

Also, the study of Grimmelikhuijsen (2010) shows that the transparency, on a high and a low level, affects in a negative way the perceived competence of a local administration. Also, the results of the study suggest that a high transparency does not positively influence the perceived morality of a city council, and, moreover, the transparency has not an influence on perceived kindness of a city council. 
McIvor et al. (2002) show that the most of the public sector organizations embrace the Internet to interact with citizens and to be more responsive to their needs. Also, the study shows that taking into consideration the high potential of Internet technologies to improve the operations of the public sector organizations, there is a stringent need to focus on this issue.

The study initiated by Grimmelikhuijsen \& Welch (2012) shows that the political composition of the city council influences the transparency. Also, the environmental problems are positively associated with the information policy transparency. The governments with larger environment budgets are more susceptible to engender policy transparency. On the other hand, the presence of some industries in a municipality negatively influences the transparency. One reason for this might be that industries try to convince the local governments not to disclose some significant information.

Another study that proves the fact that the political factors influence the transparency in local governments belongs to Araujo \& Tejedo-Romero (2016). Also, the same study finds that the transparency index is strongly influenced by the electoral turnout, a lower level of the electoral participation leading to a higher level of the transparency index. On the other hand, the results find that the political ideology is negatively correlated with the transparency index. That means the municipalities governed by left-wing parties are less transparent than those governed by the right-wing parties. Moreover, the cities with a greater population, employment rate, and investments are more transparent than the others. Galera et al. (2014) find evidence that a country's administrative culture is a significant determinant of information transparency on sustainability. Otherwise, the results of the study reveal that the level of a country's development and the quality of governance do not undoubtedly involve a more transparent behavior by the local government.

Relly \& Sabharwal (2009) show that there is a strong relationship between e-government and telecommunication technologies and governmental transparency. Otherwise, the results of the study do not reveal that some important variables such as the access-to-information laws, a developed level of egovernment, and the democracy influence the perception of transparency of government policymaking. On the other hand, according to the Relly \& Sabharwal (2009), other variables such as telecommunication infrastructure, free press influence the perception of transparency of government policymaking.

However, Pina et al. (2010) find evidence that, although the citizens expect information and communication technologies to increase transparency by empowering them to monitor government performance, the Interned is only an aid for the moment, and it is not yet an efficient environment to ease the policy discussion, the consultation of citizens, or any other purposeful democratic inputs into the policy-making mechanism.

Pallot (2001) investigates the transparency in New Zealand by examining the most recent reform undertaken by the local governments in 1998. The reform consisted in an introduction of a longterm financial planning regime under the Local Government (No. 3) Act 1996. The study analyzes the factors influencing the legislation and describes the requirements of the new regulations and finds that the new regime is the right direction to follow by the New Zealand local governments.

Also, the study of Mossberger et al. (2013) investigates the transparency in 75 of the largest United States cities, examining the use of social networks such as Facebook and Twitter between 2009 and 2011. The study is represented by a content analysis of the cities websites, and the results find that the cities of the United States tend to be more open and interactive, indicating a significant variation of interactivity index from $11 \%$ to $96 \%$. Also, other studies (Tolbert \& Mossberger, 2006) suggest that there is a statistically significant linkage between trust and using the websites of local administrations.

Otenyo \& Lind (2004) admit the fact that the Internet changed the concept of transparency, given that it can enhance the democratic position of citizens towards the administrative of political 
decisions. Although the problems associated with accessibility give some particular challenges, the governance via the Internet is aggressively increasing.

Moreover, Ohashi (2009) investigates the effects of transparency in the case of bidder qualification process in Japan, a country that is descending in the anticorruption ranking, from the 18th position in 1996 to the 20th in 2004. The analysis is based on the data related to all public projects offered for bidding by the government from 2001 to 2004, and the results reveal that the improving transparency on government expenditure has a beneficial effect by reducing the expenditure on procurement with more than $8 \%$.

All the evidence from the literature points to the fact that transparency is considered a key issue in the whole context of public organizational management. Although it is (or can be) influenced by a complex mix of factors, an increased level of transparency exhibits many varieties of impacts on stakeholders' decisions and the ability to have an accurate assessment of the use of resources and performance. One of the most common methodologies used to determine this level of transparency is to design and compute a disclosure index (based on a predetermined checklist). We will employ this methodology in the following sections to determine the aggregate level of disclosure for a sample of Romanian municipalities.

\section{Index design and transparency assessment methodology}

Devising and applying an index to determine the overall level of disclosure for an organization provides an adequate frame for the assessment of the level of transparency exhibited by reporting entities. Furthermore, if we consider capital disclosure as a prominent target for our research, we can observe in the literature the employment of content analysis and the construction of disclosure indices by matching the items of the drafted checklists with practical disclosures from official reports of different types of organizations (Williams, 2001; Guthrie \& Abeysekera, 2006), hence determining the aggregate disclosure level for each component.

For our study, we set our grounds for constructing the disclosure index on the model proposed by Ştefănescu et al (2016), using the six-tier capital structure from the Integrated Reporting Framework (see the left columns of Table 1). The original draft index was based on both quantitative and qualitative sub-indices (using additional provisions from the GRI guidelines). Within our study, we focus on the quantitative side, checking the amount of information presented by reporting entities.

Our test sample consists of 41 Romanian municipalities (the county residence cities and Bucharest, the nation's capital). This criterion of selection is assumed to induce a representative trait to our study as these municipalities are both large in size (in their respective counties) and important from an administrative point of view (as most of local and regional administration structures are located in these cities). The comprehensive list of municipalities and their respective county can be found in Table no. 2, alongside the disclosure index values.

Given the fact that the minimal disclosure level is merely regulated by specific legislation (the Local Public Administration Law no. 215/2001), we can make the underlying assumption that many municipalities resume to a compliance reporting behaviour. In this respect, we make adjustments to the original convoluted structure of the quantitative index devised by Ştefănescu et al (2016) and re-draft the list of items so that it would better fit the targeted disclosure level for Romanian municipalities (adapted to the actual reporting practice). 
Table 1

Disclosure index design

\begin{tabular}{|c|c|c|}
\hline \multicolumn{2}{|c|}{$\begin{array}{l}\text { Index developed by Ştefănescu et al (2016) using }<\text { IR }>\text { and } \\
\text { GRI }\end{array}$} & $\begin{array}{l}\text { Refined index for the current } \\
\text { study }\end{array}$ \\
\hline Sub-index & Disclosure proxy items & Disclosure items \\
\hline \multirow{3}{*}{ Financial } & Economic performance $[33,(3) \%]$ & \multirow{3}{*}{$\begin{array}{l}\text { - Revenues and expenditure } \\
\text { - Financial statements } \\
\text { - Public acquisitions } \\
\text { - Budgetary execution account }\end{array}$} \\
\hline & $\begin{array}{llll}\text { Financial costs incurred by externalities } \\
{[33,(3) \%]}\end{array}$ & \\
\hline & Financial accountability $[33,(3) \%]$ & \\
\hline \multirow{2}{*}{ Manufactured } & Inputs and deliverables [50\%] & \multirow{2}{*}{$\begin{array}{l}\text { - Property statements } \\
\text { - Investments }\end{array}$} \\
\hline & Tangible resources and infrastructure [50\%] & \\
\hline \multirow{3}{*}{ Human } & Work conditions $[33,(3) \%]$ & \multirow{3}{*}{$\begin{array}{l}\text { - Personnel } \\
\text { - Equal employment opportunities }\end{array}$} \\
\hline & Labor practices $[33,(3) \%]$ & \\
\hline & Human rights $[33,(3) \%]$ & \\
\hline \multirow{5}{*}{ Intellectual } & Innovation [20\%] & \multirow{5}{*}{$\begin{array}{l}\text { - Legislation } \\
\text { - Information systems and } \\
\text { Organizational chart }\end{array}$} \\
\hline & Intangible infrastructural assets [20\%] & \\
\hline & Information technology [20\%] & \\
\hline & Intellectual property [20\%] & \\
\hline & Organizational structures [20\%] & \\
\hline \multirow{3}{*}{$\begin{array}{l}\text { Social } \\
\text { and } \\
\text { relationship }\end{array}$} & Product or service responsibility [33,(3)\%] & \multirow{3}{*}{$\begin{array}{l}\text { - Events and partnerships } \\
\text { - Objectives } \\
\text { - Data availability for the public }\end{array}$} \\
\hline & Program and policies effectiveness $[33,(3) \%]$ & \\
\hline & Connections with society $[33,(3) \%]$ & \\
\hline \multirow[b]{2}{*}{ Natural } & Environmental relationships [50\%] & \multirow[b]{2}{*}{ - Environment } \\
\hline & $\begin{array}{l}\text { Environmental impact and use of resources } \\
\text { [50\%] }\end{array}$ & \\
\hline
\end{tabular}

Source: authors' projection, based on Ştefănescu et al (2016)

Therefore, as we can observe in Table 1, for the financial capital tier we check for the presentation of revenues and expenditure, the publication of the entire set of financial statements, disclosure of public acquisitions, as well as the presentation of the budgetary execution account (which is considered of paramount importance in the case of public sector entities). On the manufactured capital side, we assess two instances of disclosure: the property statements (preferably to be disclosed distinctly for each item of property) and the investment plan (with focus on infrastructure improvement and increase in size). The human capital revolves around disclosed information about the personnel (number, structure, responsibilities, CVs, etc.) and equal employment opportunities (as the dynamic of human resources is subject to public display). The intellectual capital tier is largely based on legislation (employment of specific laws and ordinances, as well as the issuance of local decisions, impacting the community) and information about the city hall (both general and organizational). The social and relationship capital is focused on three main disclosure items: disclosure of public events and agreed partnerships between municipalities and stakeholders; the presentation of the municipalities' objectives to the citizens in accordance with their management plan, and the society's ability to access data and information produced by the municipalities (through various tools). Last, but not least, the final item of disclosure related to the natural capital is focused on information about the environment. 
The sources of data for our study are mainly based on official documents from the last (e.g. Mayor's report, financial statements, budgetary execution account, property statements, strategic documents, etc.), as well as elements of e-disclosure (information presented directly on the official website).

The encoding for the elements of disclosure is binary (attributing 1 if the element is disclosed and, by contrast, 0 if there is no evidence of disclosure for the element). As we reduce the number of items in the refined checklist, we introduce a scale for the complexity of disclosure (scored from one to five, according to the amount of information presented). In case of the items which are based on official documents (e.g. financial statements; budgetary execution account), the scores are attributed according to the completeness of the set of information. In the case of generic disclosure elements (with a larger extension), if the municipalities merely present KPIs and numeric indicators, lower scores are attributed. On the other hand, if additional details, explanations and justifications are provided, higher (or maximum) scores are attributed.

After encoding the disclosure elements and scoring the ones which are actually presented in the reporting set, we compute the disclosure index value for each municipality, using the following formula:

$$
D I=\frac{\sum_{i=1}^{n} d i * \frac{s}{5}}{n}
$$

where: DI - disclosure index; $\mathbf{i}$ - number of disclosed items (with the attributed value of 1); $\mathbf{d}_{\mathbf{i}}$ - marker of disclosure; $\mathbf{s}$ - score attributed to the disclosed item (from 1 to 5); $\mathbf{n}$ - total number of disclosure items from the disclosure checklist

Computing the values using this formula, we can obtain the overall level of disclosure exhibited by Romanian municipalities. From here on, we can provide interpretations and provide analytical insights, based on the composition of the index and the emphasis placed on each capital or item of disclosure.

\section{The transparency level of Romanian municipalities: data analysis and discussion}

Continuing the logical flow grounded in the literature (outlined in a previous section of this paper) as well as public scrutiny, we start our analysis from the assumption that the level of transparency is impacted by a myriad of factors. Whether we are considering that municipalities merely resume to complying with legal disclosure requirements or they deliberately create a level of information asymmetry, the assumed level of transparency should exhibit low values (towards the lower bound of the scoring scale).

From Table 2, we can observe some interesting results in contrast with the previously stated assumption. More precisely, we can see that many municipalities present elevated overall levels of transparency. From the entire sample of municipalities, we can observe higher levels of transparency for the municipalities from the central, western and north-western parts of Romania. This could be explained by the fact that many municipalities from these regions are set in communities with a higher level of life quality. Also, the development of the regions from an economic point of view enables them to present more information about their projects and strategy implementation status.

\section{Comprehensive list with municipalities and disclosure index values}

Table 2 


\begin{tabular}{|c|c|c|c|c|c|}
\hline Municipality & County & $\begin{array}{l}\text { Disclosure } \\
\text { index }\end{array}$ & Municipality & County & Disclosure index \\
\hline Alba Iulia & Alba & 0,70 & Miercurea Ciuc & Harghita & 0,56 \\
\hline Alexandria & Teleorman & 0,66 & Oradea & Bihor & 0,57 \\
\hline Arad & Arad & 0,81 & Piatra Neamţ & Neamts & 0,53 \\
\hline Bacău & Bacău & 0,63 & Pitesti & Argeş & 0,41 \\
\hline Baia Mare & Maramureş & 0,59 & Ploieşti & Prahova & 0,46 \\
\hline Bistriţa & $\begin{array}{l}\text { Bistriţa- } \\
\text { Năsăud }\end{array}$ & 0,43 & Râmnicu Valcea & Vâlcea & 0,46 \\
\hline Botoşani & Botoşani & 0,67 & Reşiţa & $\begin{array}{l}\text { Caraş } \\
\text { Severin }\end{array}$ & 0,63 \\
\hline Brăila & Brăila & 0,57 & Satu Mare & Satu Mare & 0,60 \\
\hline Braşov & Braşov & 0,59 & Sfantu Gheorghe & Covasna & 0,56 \\
\hline Bucureşti & $\begin{array}{l}\text { Bucureşti- } \\
\text { Ilfov }\end{array}$ & 0,54 & Sibiu & Sibiu & 0,67 \\
\hline Buzău & Buzău & 0,50 & Slatina & Olt & 0,64 \\
\hline Călăraşi & Călăraşi & 0,57 & Slobozia & Ialomiţa & 0,39 \\
\hline Cluj-Napoca & Cluj & 0,67 & Suceava & Suceava & 0,51 \\
\hline Constanţa & Constanţa & 0,49 & Targoviste & Dâmboviţa & 0,43 \\
\hline Craiova & Dolj & 0,59 & Târgu Jiu & Gorj & 0,74 \\
\hline Deva & Hunedoara & 0,59 & Târgu Mureş & Mureş & 0,66 \\
\hline $\begin{array}{l}\text { Drobeta Turnu } \\
\text { Severin }\end{array}$ & Mehedinţi & 0,43 & Timişoara & Timiş & 0,67 \\
\hline Focşani & Vrancea & 0,36 & Tulcea & Tulcea & 0,60 \\
\hline Galaţi & Galaţi & 0,59 & Vaslui & Vaslui & 0,73 \\
\hline Giurgiu & Giurgiu & 0,54 & Zalău & Sălaj & 0,69 \\
\hline Iaşi & Iaşi & 0,53 & & & \\
\hline
\end{tabular}

Source: authors' projection

Also, a matter of particular interest is represented by the disclosure patterns. As we can observe from Table 3, many municipalities approach certain elements of the six capitals. However, not in all cases the level of disclosure complexity is the same. If we analyze the elements of financial capital from our checklist, we can observe that almost all the municipalities from the sample offer a detailed breakdown of the revenues and expenditure in their reporting set. On the other hand, very few municipalities (less than a quarter) publish their financial statements for public display online. Information regarding public acquisitions is disclosed by approximately three quarters of the municipalities; however, the levels of complexity for this type of disclosure is lower than in the case of the other items from the checklist (meaning that many municipalities consider this disclosure requirement mostly a compulsory way of justifying their acquisition plan, but are not inclined to give a detailed view and resume to a brief presentation). Last, but not least, the budgetary execution account is presented in full by most of the municipalities, being viewed as a financial performance assessment tool.

With regard to the manufactured capital, we can observe in Table 3 that all municipalities issue (or include in their reporting output) property statements and, furthermore, most of them publish information about their investment plan and status. However, on both accounts, the level of complexity is medium and the issues addressed are approached merely from a legal requirement point of view. From the human capital perspective, only a few municipalities present information on the personnel 
working for the local administration structures (and the ones which actually disclose resume mainly use KPIs and brief description of the structures). On the other hand, all municipalities publish information equal employment opportunities, which could be explained by the fact that the employment advertisement in the Romanian municipalities is subject to public display (by legal provisions). Therefore, there is a level medium level of disclosure regarding these opportunities.

The intellectual capital, structured according to our index design, exhibits higher levels of transparency than the other instances. In terms of legislation (both used and produced), all municipalities disclose a high and rather complex amount of information. This is connected to the fact that the legislation employed in the operational activity of the public administration unit is mandatory, the same as the decisions issued by the governing structures (in this case, the Local Councils). For the social and relationship capital tier, we can notice that events and partnerships are presented in the reporting output by approximately a quarter of the municipalities from the sample. The interesting fact is that the amount and complexity of this information is elevated as it is in the interest of the public administration unit to facilitate brand capitalization as an effect of these events and partnerships. On a different note, disclosing the objectives and ensuring the connection with the public by enhancing the availability of data is considered important by most municipalities. Also, the natural capital benefits from attention from three quarters from the municipalities, but on a lower level, with brief presentations of information regarding the impact on the environment.

Table 3

Average scores attributed to disclosed items

\begin{tabular}{|l|c|c|}
\hline \multicolumn{1}{|c|}{ Disclosure items } & $\begin{array}{c}\text { Municipalities } \\
\text { count }\end{array}$ & $\begin{array}{c}\text { Average score for disclosed } \\
\text { items }\end{array}$ \\
\hline - Revenues and expenditure & 40 & 4,95 \\
- Financial statements & 9 & 3,56 \\
- Public acquisitions & 33 & 2,70 \\
- Budgetary execution account & 38 & 5,00 \\
\hline - Property statements & 41 & 3,29 \\
- Investments & 37 & 3,24 \\
\hline - Personnel & 5 & 3,60 \\
- Equal employment opportunities & 41 & 3,61 \\
\hline - Legislation & 41 & 4,10 \\
- Information systems and organizational chart & 35 & 4,06 \\
\hline - Events and partnerships & 14 & 4,28 \\
- Objectives & 31 & 3,25 \\
- Data availability for the public & 37 & 3,86 \\
\hline - Environment & 33 & 2,84 \\
\hline
\end{tabular}

Source: authors' projection

Overall, from Table 4 we can observe that the level of information disclosed by the municipalities from the sample is slightly over the 50\% marker. In other words, the Romanian municipalities from our sample consider more than half of the generic information about the six capitals enclosed in our disclosure index. The range of values for the overall index is quite extended (from $36 \%$ of the information disclosed to $81 \%$ - for the most transparent municipality). In this respect, the lower bound of the range consists of municipalities which rely mostly on information which is 
mandatory (required by law), whereas municipalities from the upper bound either have a more detailed approach on mandatory information, or they voluntarily publish information (closely connected with the structure of our index, based on the six capitals).

If we breakdown the index on the capitals, we can observe by comparing the maximum value of the index components that there are municipalities which are close (or even reach) the target (or "ideal") level of disclosure. On the other hand, there are several municipalities in the sample which do not present information on the social and relationship and natural capitals at all. Basically, these are municipalities from the first mentioned category - relying on the lower bound of mandatory disclosure. For the intellectual capital, we find that the average disclosure level for the constituting items is close to the target score per capital (which is explained by the fact that legislation and information systems are highly prioritized in the reporting set by the municipalities).

Table 4

Disclosure index -statistics

\begin{tabular}{|c|c|c|c|c|c|c|c|}
\hline Indicator & Financial & Manufactured & Human & Intellectual & $\begin{array}{l}\text { Social and } \\
\text { relationship }\end{array}$ & Natural & \\
\hline $\begin{array}{l}\text { Highest } \\
\text { score per } \\
\text { capital }\end{array}$ & 0,29 & 0,14 & 0,14 & 0,14 & 0,21 & 0,07 & Aggregate \\
\hline Minimum & 0,07 & 0,03 & 0,01 & 0,04 & 0,00 & 0,00 & 0,36 \\
\hline Maximum & 0,26 & 0,14 & 0,13 & 0,14 & 0,20 & 0,07 & $\mathbf{0 , 8 1}$ \\
\hline $\begin{array}{l}\text { Standard } \\
\text { deviation }\end{array}$ & 0,04 & 0,03 & 0,02 & 0,03 & 0,05 & 0,02 & $\mathbf{0 , 1 0}$ \\
\hline Average & 0,18 & 0,09 & 0,06 & 0,11 & 0,11 & 0,03 & 0,57 \\
\hline
\end{tabular}

Source: authors' projection

Through our findings, we manage to show that the level of transparency for Romanian municipalities is higher than assumed and the balance between financial and non-financial information is ensured in the reporting output by the analyzed entities. There is, however, evidence of disparities between municipalities from different geographical areas, as well as component-wise, which means that the decision to disclose more information than mandatory is prone to be influenced by a multitude of factors and dimensions. The attained transparency level is actually a mixed effect of the governing structures' intent to abide the requirements provided by the law and, also, to provide information to the public (towards which they are accountable) about the use of and effects on resources.

\section{Conclusions, limitations and perspectives}

Transparency has indeed been in the spotlight, with research emerging from both the academic literature and practice. Studies show that transparency is connected through a wide range of interactions to a large set of economic phenomena and factors, but - most important - it is a mean to discharge accountability towards the public (by presenting a high amount of information about the organization's activity). In addressing the assessment of the transparency level of an organization, it is not sufficient anymore to consider merely the financial dimension, but also the instances of nonfinancial information. To support this claim, we place emphasis on the emergence of new reporting trends which hold elements of non-financial information (such as social and environmental) as important as the financial one. 
In this respect, the Integrated Reporting Framework and the GRI guidelines provide the adequate frame to make the assessment of transparency levels for public sector entities (mainly based on the layers of the six capitals). Within our study, we refine a previous disclosure model based on the six-capital model and adapt it to the national legislation (restructuring the disclosure items so they can be properly analyzed in the actual reporting output). Applying the refined disclosure model on a sample of Romanian municipalities, we find that the overall transparency level is higher than expected, but the amount and complexity of the information disclosed highly differs (both between different municipalities, and for different capital instances within the same reporting output of a municipality). Explanations for our findings also differ in close connection to the typology of disclosure and is influenced by several factors (including the mandatory/voluntary status of information, impact on the municipality's image and the scope of the municipality's activity - with regard to legislation).

The main limitation of our study are connected to the design of the index - which, at this point is drafted solely on a quantitative basis. Also, the scoring for the complexity of the disclosure items is prone to a level of subjectivity (and it is, to some extent, self-explanatory as we have only a measure of target disclosure taken from the municipalities which, in our opinion, achieve this level). Last, but not least, our disclosure checklist has a low number of items. To overcome this limitation, we could break down even further and increase this number items (addressing specific issues of financial and nonfinancial information and reducing the subjectivity level by resorting solely to the binary encoding). In terms of research outlook, we consider the inclusion of a qualitative dimension in our analysis (based on principles of reporting), as well as extending our study from a static design (for just one year of reporting) to a panel study (to have a wider view on how the level of transparency evolves over time).

\section{Acknowledgement}

This work was supported by a grant of the Romanian National Authority for Scientific Research and Innovation, CNCS - UEFISCDI, project number PN-II-RU-TE-2014-4-0265.

\section{References}

1. *** Public Administration Law no. 215/2001, republished and updated.

2. Araujo, J. F. F. E. D., \& Tejedo-Romero, F., 2016. Local government transparency index: determinants of municipalities' rankings. International Journal of Public Sector Management, 29(4), 327-347.

3. Armstrong, C. L., 2011. Providing a clearer view: An examination of transparency on local government websites, Government Information Quarterly, 28(1), 11-16.

4. Bannister, F., \& Connolly, R., 2011. The Trouble with Transparency: A Critical Review of Openness in e-Government, Policy \& Internet, 3(1), 1-30.

5. Bonsón, E., Torres, L., Royo, S., \& Flores, F., 2012. Local e-government 2.0: Social media and corporate transparency in municipalities, Government information quarterly, 29(2), 123-132.

6. Brooks, J., 2000. Labour's modernization of local government. Public Administration, 78(3), 593612.

7. Galera, A. N., de los Ríos Berjillos, A., Lozano, M. R., \& Valencia, P. T., 2014. Transparency of sustainability information in local governments: English-speaking and Nordic cross-country analysis, Journal of Cleaner Production, 64, 495-504.

8. Gandía, J. L., \& Archidona, M. C., 2008. Determinants of web site information by Spanish city councils, Online Information Review, 32(1), 35-57.

9. Grimmelikhuijsen, S. G., \& Welch, E. W., 2012. Developing and testing a theoretical framework for computer-mediated transparency of local governments, Public administration review, 72(4), $562-571$. 
10. Grimmelikhuijsen, S. G., 2010. Transparency of Public Decision-Making: Towards Trust in Local Government?. Policy \& Internet, 2(1), 5-35.

11. Grimmelikhuijsen, S., Porumbescu, G., Hong, B., \& Im, T., 2013. The effect of transparency on trust in government: A cross-national comparative experiment, Public Administration Review, $73(4), 575-586$.

12. Guthrie, J., Abeysekera, I., 2006, Content analysis of social, environmental reporting: What is new?, Journal of Human Resource Costing \& Accounting, 10(2), 114-126.

13. Kim, S., \& Lee, J., 2012. E-participation, transparency, and trust in local government, Public Administration Review, 72(6), 819-828.

14. Kopits, M. G., \& Craig, M. J., 1998. Transparency in government operations, 158, International monetary fund.

15. Kristiansen, S., Dwiyanto, A., Pramusinto, A., \& Putranto, E. A., 2009. Public sector reforms and financial transparency: Experiences from Indonesian districts, Contemporary Southeast Asia: A Journal of International and Strategic Affairs, 31(1), 64-87.

16. McIvor, R., McHugh, M., \& Cadden, C., 2002. Internet technologies: supporting transparency in the public sector, International Journal of Public Sector Management, 15(3), 170-187.

17. Meijer, A., 2013. Understanding the complex dynamics of transparency, Public Administration Review, 73(3), 429-439.

18. Mossberger, K., Wu, Y., \& Crawford, J., 2013. Connecting citizens and local governments? Social media and interactivity in major US cities, Government Information Quarterly, 30(4), 351-358.

19. Ohashi, H., 2009. Effects of transparency in procurement practices on government expenditure: A case study of municipal public works, Review of Industrial Organization, 34(3), 267-285.

20. Otenyo, E. E., \& Lind, N. S., 2004. Faces and phases of transparency reform in local government, International Journal of Public Administration, 27(5), 287-307.

21. Pallot, J., 2001. Transparency in local government: antipodean initiatives, European Accounting Review, 10(3), 645-660.

22. Pina, V., Torres, L., \& Royo, S., 2007. Are ICTs improving transparency and accountability in the EU regional and local governments? An empirical study, Public administration, 85(2), 449-472.

23. Pina, V., Torres, L., \& Royo, S., 2009. E-government evolution in EU local governments: a comparative perspective, Online Information Review, 33(6), 1137-1168.

24. Pina, V., Torres, L., \& Royo, S., 2010. Is e-government leading to more accountable and transparent local governments? An overall view, Financial Accountability \& Management, 26(1), 3-20.

25. Relly, J. E., \& Sabharwal, M., 2009. Perceptions of transparency of government policymaking: A cross-national study, Government Information Quarterly, 26(1), 148-157.

26. Ştefănescu, C.A., Oprişor, T., Sîntejudeanu, M.A., 2016. An original assessment tool for transparency in the public sector based on the integrated reporting approach, Journal of Accounting and Management Information Systems, 15(3), 542-564.

27. Williams, S.M., 2001. Is intellectual capital performance and disclosure practices related? Journal of Intellectual Capital, 2(3), 192-203. 